Research Paper

\title{
Business Law Service in the Workplace as a Career Trend or to Wage Erosion - Minimum Wage
}

\section{Naumovski Ljupcho ${ }^{1}$}

${ }^{1}$ Private Higher Education Institution, Euro College, Kumanovo, Republic North Macedonia.

\section{Article History}

Received:

25.12.2020

Revised:

20.01.2021

Accepted:

20.02.2021

*Corresponding Author:

Naumovski Ljupcho

Email:

1_naumovski@yahoo.com

This is an open access article, licensed under: $\mathrm{CC}-\mathrm{BY}-\mathrm{SA}$
Abstract: The research motivated by the importance of the minimum wage, and to make the relevance of this paper based on inconsistencies in the equality of legal regulation of the minimum wage. The purpose of the research is an overview of CEEC in the economic field/relations regarding the current demand for the minimum wage to the workplace. Methodology used are the dialectical method with the methods of formal-logical, systemstructural, comparative legal and statistical analysis through the study of monographs, scientific literature, analysis of existing laws and regulations, data synthesis. Based on this research concluded that the importance of the level of payment, but not the inadmissibility of determining a payment less than the minimum wage. However, for the minimum wage to fulfil its economic, social and legal function today, it must be set at a sufficiently appropriate level.

Keywords: Benefits, Minimum Wage, Poverty, Worker. 


\section{Introduction}

For economists, the 20th century is a century of "human capital" [1], and the 21 st century is a century of development of that "human capital" and the opportunity for effective and efficient use. The working model is based and realized based on Labor legislation - labor relations, Minimum wage, Policies for passive employment services based on low coverage and unemployment benefits, and Flexible salary formation mechanisms. The owner of the means of production and the owner of the labour force, entering into employment, establish an important condition for each other - salary.

Europe as shown in Figure 1, is in the dynamics of market liberalization, i.e. employment and the most current social conditions. A factual picture of reality is systemic pressure on wage compensation. In reality, the legal system of every country in the world and the EU enables the guaranteed right to work, the free movement of people, so that in general the European labour market is more branch/sectorally developed, which is a consequence of individual Erosion of compensation work, and thus employment.

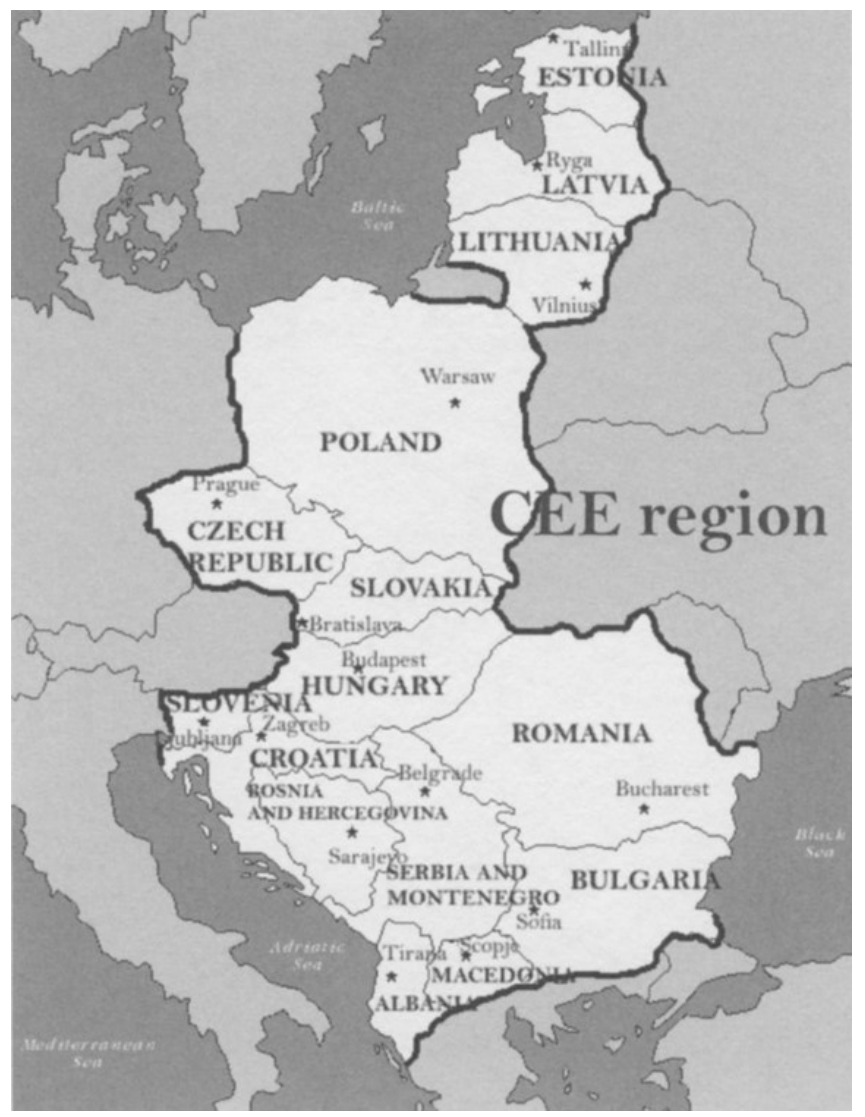

Figure 1. Map of Central and East Europe [1]

The member countries make up a heterogeneous whole by size, population, level of development and institutional affiliation. Nine countries belong to the European Union (Estonia, Latvia, Lithuania, Poland, Czech Republic, Slovakia, Hungary, Slovenia, Croatia, Romania, Bulgaria) joined in several waves (2004, 2007, 2013); five are members of the euro zone (Estonia, Latvia, Lithuania, Slovakia, Slovenia) and two (Montenegro and Bosnia and Herzegovina) use the €uro currency as their currency without being members of the zone, five other countries of the Western Balkans (Albania, Bosnia and Herzegovina, North Macedonia, Montenegro, Serbia) are in the process of acceding to the European Union and are therefore subject to European regulations deriving from their status as future members [2].

Production requires tools, objects of labour, and of course, workers. Professional $/$ special knowledge, high professional training, general human culture are all guarantors for highly efficient 
work or production. A relevant element of labour organization is the organization and maintenance of the workplace.

The importance of the element of organization and maintenance of jobs in the system of elements of labour organization and part determines the relevance of labour.

\section{Workplace}

The concept of "workplace" is ambiguous and allows a variety expert interpretations. Essential definitions contain resolutions at the ILO - the workplace is a position filled by an employee created to enforce such a contract. In other words, there are as many jobs as there are in a given situation concluded employment contracts. Exactly the number of contracts contains the statistics for job movement - working hours, level and structure of the remuneration [3].

Let us clarify the definitions. The workplace is the primary link in the production process in creating wealth, an indicator of the organization of labour because it characterizes the quality and coordination of work as a whole. The workplace is a zone of work activities of a contractor or a group of contractors to perform certain work. The primary link that represents the main elements of the production process. Enterprises, production sectors and jobs are correlated, so their functioning has a direct impact on the general rhythm of collective labour and work results. Any Workplace has its own specific characteristics related to the peculiarities of the organization of the production process, the different forms of the specific labour force. The condition of the workplaces, their organization directly determines the level of organization of work in the enterprise.

And most importantly, the organization of the workplace directly forms the work environment in which the worker is constantly in production, and thus affects his well-being, mood, performance and, ultimately, labour productivity.

\section{Salary: Theories}

Wages are the main source of increased well-being, mood, Performance and, on the end, on the labour productivity of the working population, i.e. income. Wages him represent working/paid a share in the individual consumer fund of the national income in monetary terms. The work must be paid (axiom). Living conditions, meeting daily needs, the ability to maintain his working capacity depend on the size of the salary received. In the pyramid of workers incentives, the salary is at the highest place.

The state with government regulation of the market (taxes, subsidies, fixed prices), and through active government intervention manages wages to be a socio-economic parameter for determining the standard of living, the general effective demand of the population in the EU countries, and of the rest of the population in the regions. Most of the income for consumption is from salaries, with a decisive impact on the quantity of good for general consumption and the price level.

Two basic concepts for determining the nature of wages: a) Wage is the cost of labour, i.e. value and dynamics are a result of market factors, i.e. supply and demand; b) wages are a monetary expression of the value of labour, i.e. production conditions and market factors through supply and demand, enable equalization of wages from the price of labour. On the essence of wages, adheres to the theory of marginal productivity and believes that a stable amount of money in circulation is needed to increase the "marginal efficiency of capital", business activity and employment of the population [4]. This can be achieved through a system of government measures aimed either at an absolute increase in money in "business communication" or at a relative increase. First is realized with the so-called controlled inflation, secondly with lower wages which, like any income, should increase the inclination towards consumption and expand the consumer market. The conclusion is supported with its "basic psychological law": the lower the income, the lower is part of the saved income, a higher part of the income goes to consumption. This provision is the decisive basis for Keynes' program for freezing and reducing wages. Supporters of the concept of "regulated wages" by Keynes [4], defend its point of view that for to increase the level of employment of workers, necessary is to regulate wages by limiting their growth. Decades of economic growth, followed by global wage stagnation and lagging behind labour productivity growth. Employees are not paid enough to live with dignity, inadequate social security networks her exacerbate the already high inequality and poverty.

Wage inequality is on the rise, with that the wages of the highest-paid workers are rising several times faster than the average. The share of labour income in GDP is declining, and wage earners do not receive their share of the profits through higher wages. At the same time, the European Trade 
Union Confederation ("Europe needs wage growth", campaign) called for wage increases, wage convergence for higher wages and collective bargaining agreements within the EU.

\section{EU Salary: History, Definition at International Level and Acts}

International salary guarantees include [5]:

a) Depending on the body that adopted the normative act - in the UN acts, ILO acts, regional acts, and international agreements (concluded).

b) Depending on the legal force of these acts - in mandatory, normative acts and international legal acts for recommendation

c) According to the nature of workers' rights (individual and collective).

The main international legal acts regulating wages are [5]:

- Universal Declaration of Human Rights (1948); International Covenant on Economic, Social and Cultural Rights (1966).

- $\quad$ European Social Charter (amended on 03.05.1996);

- $\quad$ ILO Convention No. 95 of 01.07.1949 "On the protection of wages"; Issue 100 of 29 June 1951 "On Equal Rewards for Men and Women of Equal Work", No. 111 of 25 June 1958 "On Discrimination in the Field of Labor and Occupation", No. 131 (1970) "On setting a minimum wage with special attention to developing countries" and others. Art. 23 of the Universal Declaration "Everyone, without any discrimination, has the right to equal pay for equal work (paragraph 2), and paragraph 3 speaks of the right to a fair and satisfactory reward, to ensure a decent human existence for himself and his family, and supplemented if required, by other means of social security.

The International Covenant on Economic, Social and Cultural Rights of 1966 classifies wages as fair and favorable working conditions.

Includes compensation that provides at least all workers: 1) fair wages and equal pay for work of equal value without any difference, and especially women should be guaranteed working conditions by those who use men with equal pay for equal work; 2) a satisfactory existence for themselves and their families by following per under the provisions of this Covenant" (Article 7).

The Decree for workers (Edward III 1349) gave the worker MW in medieval England, in shortage of labour after the black plague, which led to wage increases and dissatisfaction among all property owners (who encouraged Edward to set a maximum wage). The Statute for Workers amends the Workers' Decree 1351 by setting increased penalties for those who paid labour above the established value. The statute (1389) binds wages with the price of food, which in time, the peace judge to determine the maximum wages, started and formally take them determines the minimum wage. This was formalized by the issuance of a minimum wage for workers in the textile industry (King James I, 1604). Capitalist England in the 19th century repealed wage legislation, advocating for the free choice of employers, and therefore a century of workers' revolts, which affected many other industrialized nations. Capitalist England in the 19th century repealed wage legislation, advocating for a free decision of employers, and therefore called that is a century of workers riots, which also affected many other industrialized countries. Initial law examples of the national minimum wage date back to 1890. The movement was originally aimed at solving the problem of the number of hours and working conditions in various industries, where the so-called shops tend to become the rule. The shops employed a large number of women and children, who were forced to work 12-14 hours a day in inhumane conditions for much lower wages. The owners of shops and industries had the same powers as the slave owners, and they considered the measures for determining the minimum wage as a forced means for forced more fair payment.

EU with Community Charter of Fundamental Social Rights of Workers in 1989 determines all kinds of work should be quite rewarding [6]. For that purpose and in consent with the measures taken in each country: a) workers must be provided with fair wages, i.e. a salary sufficient to ensure a decent standard of living." In Opinion of the European Commission [7], it is said that the search for fair wage $\mathrm{s}$ should be looked at relation to the goal of achieving productivity and growth for 
employment and promoting good relations between the social partners. Member States are encouraged to adopt policies of the realization for fair wages, with commitments for greater transparency towards wages in the labour market. The social partners were also encouraged to contribute to this process. In Austria, France, Germany, Italy, the Netherlands, Portugal and the UK are proved that exists wage inequality increased between 1993 and 1997 [8].

The Commission for employment and social policy (COM, 2001/313 final) was generally focused on the quality of work rather than specifically on the level of wages, i.e. to ensure that: "the work satisfies the content, is compatible with the professional skills and abilities of the person and will provide appropriate levels of income." The agenda (COM, 2005/33 final) for social action is indirectly related to wage issues and talks about the quality of employment and minimum income schemes i.e. systems in which tax credits and benefits or other measures are combined to achieve a minimum income rather than directly for low wages and minimum wages. The quality of work is closely related to the amount of wages. Low paid jobs are associated with poor working conditions, accompanied by inadequate benefits, pensions and inadequate training and development without them. European Parliament is with the role of monitoring and calling for action on low wages by the directive (European Parliament (2002/13 (INI)), assesses the situation in the Member States in relation to basic labour rights, with an emphasis on opposing discrimination by establishing fair minimum wages and specifically Greece, Ireland, Spain objected proof: minimum wage below 50\% of average income [9].

Council of Europe with the European Social Charter (European Social Charter ETS No.035.10, Turin, 18/10/1961 coe.int) in Art. 4 paragraph 1 "Right to a fair compensation" requires the signatory countries: Recognize the right to workers' compensation that will enable them and their families to enjoy a decent standard of living." The Council of Europe can examine the reward systems of EU Member States and assess whether they provide fair remuneration for work based on their dignity threshold, for example, estimated that in 2002 the national minimum wage in the UK (based on the rate of 2000) is too low and needs to be harmonized with Art. 4, and concludes, cannot properly assess the situation in the UK, because it failed to provide data on the net minimum wage of a family worker [5]. According to Art. 4 paragraph 1 Council of Europe Committee on Social Rights concludes, Greece, Spain, Austria, Netherlands and Slovakia are not in line with the Adequate Wages Directive, with no final conclusion on the situation in Denmark, Germany, Iceland and Norway pending further information. An EU country that is unable to acts in consent with the Social Charter, she should submit temporal schedule and publish a process showing how and when it can comply with the requirements of the Charter. The European Committee gives warnings, recommendations and additional recommendations to ensure that this country acts in consent with the "Social Charter". A decent salary threshold is up for discussion, who is the "threshold", and the decision for his changing is an internal matter of the Council of Europe's European Committee of Social Rights and are not spread. The task of collective bargaining represents the protection of workers' wages from inflation and getting part of the benefits of productivity gains [7].

The attention is aimed at an increase in average national productivity, as opposed to changes in labour productivity in specific sectors of the economy. Explanation, low productivity industries must keep pace with high productivity industries. Solidary collectively negotiation came under pressure from both governments and employers seeking local bargaining in all national and industrial negotiations. Since the 1970s, the long-term trend has been to decline section of wages in national income, although wages in many European countries lag behind productivity growth (Thorsten Schulten, 2002). This affected the economy as a whole and are actualized as a topic for discussion of low/minimum wage in Germany. Trade Union, supported by researchers from Germany, France and Switzerland her concluded the economic role of wages in the "European minimum wage policy thesis" noting that for many businesses wages are a "factor in production costs."

The question of a "decent income" and the fact that workers are not commodities, and that their income should not simply be left at the mercy of the market, the neoliberal argument is marketing to work, through the logic of the German website (jobdumping.de) created to encourage people to apply for jobs after the termination of other employees. The ILO points out why employers support the minimum wage with "so to increase productivory by motivating workers "or factor" reducing change labour ", which can be very expensive for companies" (Catherine Saget, Department of Employment Strategy, ILO). Average hourly wages in 2017: in the EU/26.76 euros per hour, and the euro area/30.33 euros per hour. So, the average salary in the countries of the European Monetary Union is higher than the EU average. According to Eurostat, in the first quarter of 2020, Romania (13\%), 
Latvia (11\%), Hungary (10\%), Czech Republic, Lithuania (9\%) and Slovakia (8.5\%) had the largest increase in average wages. For the first quarter of 2020, the wage growth in the euro area countries was $2 \%$, and in the EU countries (EU-28) $-2.7 \%$.

\subsection{Definitions of Low Wages}

The purpose of Council of Europe whether the amount of compensation for work is sufficient in a given country realized it through the European Committee of Social Rights (SEBS) which proposed $68 \%$ of gross average earnings to be considered the norm. This was reminiscent of the definitions used by the OECD, namely $2 / 3$ of the average earnings of full-time workers (stats.oecd.org/Index). The definition of Council of Europe acquired certain acceptance and became the key target of activists for low wages in the UK. According to the Council of Europe, is not a word for evaluation only, e.g. whether the national minimum wage is at or above this threshold. The Council of Europe Committee on Social Rights (ECSC) confirm will take into account other factors (taxes and social benefits). This proved to be an impossible task and ECSC announced that he is unable to determine whether governments provide satisfactory revenue or not. This committee prepared another benchmark $60 \%$ of net average earnings.

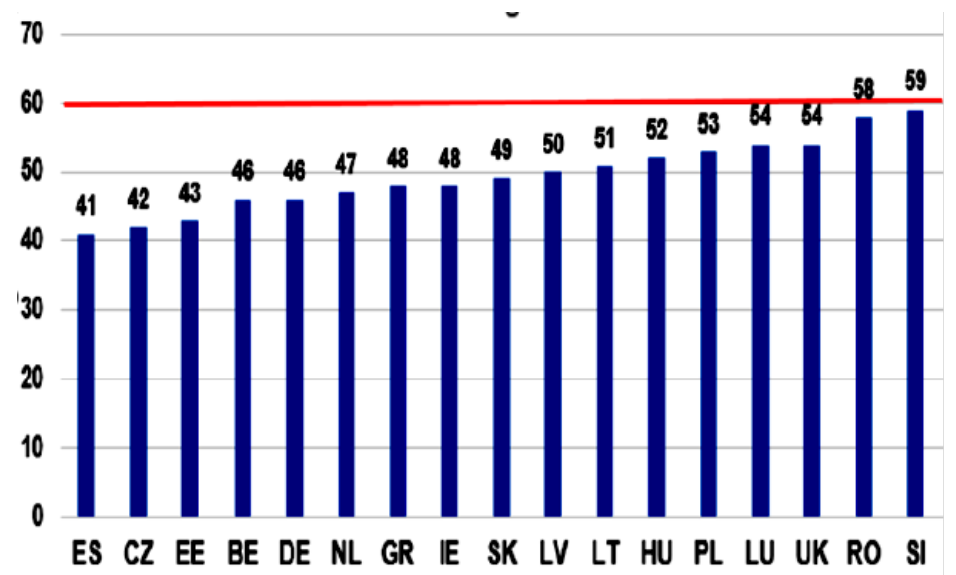

Figure 2. $17 \mathrm{EU}$ member states with legal minimum wages below $60 \%$ of the national average wage

The ETUC is highlighting the figures amid the European Commission's consultation on how to deliver on Ursula von der Leyen's pledge to ensure that workers in the EU have fair minimum wages, 28.01.2020 [10].

The decision for this change was attacked in UK from low-wage activists. Carol Murray of the Scottish Low Wage Group said this group believes in redefining does not serve just to hide overall effectiveness on the decent threshold of salary as a means with which poorer European citizens can call them their governments responsible for their policies, but they also bury her the usefulness of the definition as a tool for analysis among unnecessary complexities what they can to hope that they will expose them only statisticians in the service of member states [11].

Today, 22 EU countries are with legal national minimum wage, but most EU countries do not respect the minimum a threshold of $60 \%$ of the average salary, while in $10 \mathrm{EU}$ members $50 \%$ or less than the national average wage, as shown in Figure 2. A key feature of every goal is its comprehensibility and ease of assessment when checking the amount of salary. It is relevant if the goal is set-up for goals or purposes of collective bargaining, lobbying and campaigning across Europe.

\subsection{Legal Acts for Minimum Wage}

The first national minimum wage law in Europe is from UK (above) and it was reintroduced and extended in 1998, France (1915), Austria and Norway (1918), Germany (1923), Spain (1926) and other European countries. None clear definition of the minimum wage, and was defined as "living 
wage", "Price of workers' decency", "salary according to needs". The minimum wage depending on the country is different: by value, age (in the UK); type of work (USA); time period (monthly, in Russia and China) or types of expenses (personal/family). There are also MW laws in mutual consent of employers with "tips" of workers to determine the minimum wage. With overtime, legislation for minimum wage them changes goals, and the focus is on helping employees and families, of selfemployment and a decent standard of living.

The minimum wages are always currently an important topic in the ILO [9], on basis of the attitude "Universal and lasting peace can be established only if it is based on social justice", the Constitution of ILO in its own Preamble calls for an urgent improvement of working conditions, with "Providing adequate living from wages" (ilo.org). To date, the international field exists several definitions of minimum wages, but none is not directly seduced as universal recognized international act (conventions, recommendations, etc.). All existing "International" definitions for minimum wages are presented as collective expert opinions, set out in reports on separate meetings and conferences on internationally level. Thus, ILO experts (1967), formulated "Enough for meeting basic needs in food, clothing, housing, education and recreation of the worker, taking take it into account the economic and cultural development of each country. In some cases, the needs of the family also are taken the account in the same way as well as on the worker, in other cases, they are compensated with family allowances and other social security measures." At the same time, it is pointed out that the minimum wage "Is the lowest the permissible level of reward, which has the force of law in each country provided with fines or other appropriate sanctions." (Ibid. pp. 10-11 ilo.org) Committee of Experts of MOT notes that ,the concept of minimum wage" in the form in arising from the acts what them studies for the implementation of conventions and recommendations is in correlation with 3 clear aspects of wages": wages for the work they do perform by the employee; the wage as basic income to the employee what guarantee the existence of the employee and his family members and wages are (an element of) the cost and component of general spending of consumers. Committee of Experts of the ILO emphasizes that a number of instruments on the ILO (Part III of Recommendation No. 30, paragraph 2 of Part I of Recommendation No. 89 and Article 3 of Convention No. 131) suggests that a combination of these three aspects should be taken into account when determining the minimum.

In the twentieth century, the definition in 1967 was refined and reformulated in a "legal" style by the Committee of Experts and reads MW is the minimum amount paid to a worker for work performed or services performed in a given period, calculated basised on time or productivity, which does not it can be reduced neither by an individual nor by a collective agreement, guaranteed by law and which must be established in a way that compensates for the minimum needs of the worker and his or her family in the light of national economic and social conditions [12].

The flexibility of defining MW by the end of the 20th century is: according to the new definition, the minimum wage is not or "considered sufficient" to meet very specific urgent needs ("in food, clothing, housing, education and leisure of the worker "), And can be any" minimum amount "; not its size, but to "allow the needs of the worker and his family to be compensated"; at the same time, the needs which are compensated cease to be "urgent", become "Minimal", and generalize, losing the need for satisfaction; "The economic and cultural development of an individual country" turns into "national economic and social conditions".

The changes make the new definition of MW more accessible for use by economically weak countries that are unable to compensate for the wide range of "urgent" needs of the worker and his family members, given in the previous definition. At the same time, however, this obviously justifies the reduction of minimum wage guarantees by using more or less complex schemes in which the minimum wage itself may not be sufficient "to meet the needs" of the worker and his family (even minimal), acquiring only this quality together with some additional payments and measures that form a "way" for its determination.

Almost simultaneously, the international community of legal scholars developed its own concept, so MW is "calculated basised on time or productivity, and is a level that cannot be reduced, and its application is guaranteed by law." We emphasize: such a definition is hardly recommended for use in the development of national interpretations of MW due to its general nature.

Based on the legislative guarantees as an imperative, the concept does not establish procedures for determining the MW and does not mention the socially important goals of its establishment. This is a definition of a legal entity, without instructions for its change and development, which limits the scope of its application to purely scientific and educational tasks. 
Table 1. European Countries Signed the

ILO Conventions No. 26 (1928) and No. 131 (1970) for Minimum Wages

\begin{tabular}{|c|c|}
\hline Cou & egulation \\
\hline Belgium & $\begin{array}{l}\text { Collective agreement No. } 43 \text { of the National Labour Council (Collectieve } \\
\text { arbeidsovereenkomst } n^{\circ} 43 \text { van de Nationale Arbeidsraad) }\end{array}$ \\
\hline Bulgaria & $\begin{array}{l}\text { Decree No. } 316 \text { of } 20 \text { December } 2017 \text { (ПОСТАНОВЛЕНИЕ № } 316 \text { ОТ20 } \\
\text { ДЕКЕМВРИ } 2017 Г\end{array}$ \\
\hline Croatia & Decree NN $122 / 2017$ on the amount of the minimum wage (Uredba o \\
\hline Czech Republic & $\begin{array}{l}\text { Government Order No. 567/2006 Coll. of } 6 \text { December } 2006 \text { on the statutory } \\
\text { minimum wage, amended by Government Order No. } 286 / 2017 \text { Coll. (Narizeni vlddy } \\
\text { c. } 567 / 2006 \text { Sb.ze dne 6. prosince } 2006 \text { o minimàlnf mzdë, ve znënfnarizeni vlddy c. }\end{array}$ \\
\hline Estonia & $\begin{array}{l}\text { Government Regulation RT I, 22.12.2015, } 51 \text { on the establishment of the minimum } \\
\text { wage (Vabariigi Valitsuse maarus 'Tootasu alammaara kehtestamine') }\end{array}$ \\
\hline France & $\begin{array}{l}\text { Decree No. } 2017-1718 \text { of } 20 \text { December } 2017 \text { on the minimum wage increase (Décret } \\
n^{\circ} 2017-1719 d u 20 \text { décembre } 2017 \text { portant relèvement du salaire minimum de }\end{array}$ \\
\hline Germany & Minimum Wage Act (Mindestlohngesetz, MiLoG) \\
\hline Greece & $\begin{array}{l}\text { Act of Cabinet No. 6/2012 (28/2/2012). Law No. 4093/2012, Article 1, Paragraph. } \\
\text { IA.11 } \$ 3(12 / 11 / 2012) \text {. }\end{array}$ \\
\hline Hungary & $\begin{array}{l}\text { Government Decree No. } 430 / 2016 \text { (XII. 15.) Korm. on the Mandatory Minimum } \\
\text { Wage and on the Guaranteed Wage Minimum (A kormâny } 430 / 2016 \text { (XII. 15.) } \\
\text { rendelete a kotelezo legkisebb munkabér, és agarantâlt bérminimum }\end{array}$ \\
\hline Ireland & $\begin{array}{l}\text { The minimum wage increase, with effect from January 1st } 2018 \text {, was implemented } \\
\text { through a Statutory Instrument (S.I. } 440 \text { of 2017) (National Minimum Wage Order }\end{array}$ \\
\hline Latvia & $\begin{array}{l}\text { Regulation of the Cabinet of Ministers No. } 656 \text { on calculation of the amount of the } \\
\text { minimum monthly wage within the normal working time and minimum hourly rate. } \\
\text { Adopted on } 24 \text { November } 2015 \text {. Last amendment on } 29 \text { August } 2017 \text {, valid from } 1\end{array}$ \\
\hline Lithuania & $\begin{array}{l}\text { Resolution No. } 814 \text { of the Government of the Republic of Lithuania on the minimum } \\
\text { wage of } 11 \text { October } 2017 \text { (Lietuvos Respublikos Vyriausybés nutarimas 'Dél } \\
\text { minimaliojo darbo uzmokescio' Nr. 814) }\end{array}$ \\
\hline Luxembourg & $\begin{array}{l}\text { Law of } 15 \text { December } 2016 \text { on the modification of the article L.222-9 of the Labour } \\
\text { Code (Loi du } 15 \text { décembre } 2016 \text { portant modification de l'article L. 222-9 du Code }\end{array}$ \\
\hline Malta & National Minimum Wage National Standard Order (Subsidiary legislation 452.71) \\
\hline Netherlands & $\begin{array}{l}\text { Regulation of the Minister of Social Affairs and Employment of } 9 \text { October } 2017 \\
\text { concerning adaptation of the statutory minimum wage (Regeling van de Minister van } \\
\text { Sociale Zaken en Werkgelegenheid van } 9 \text { oktober2017, nr.2017-0000159683, tot } \\
\text { aanpassing wettelijk minimumloon per } 1 \text { januari 2018) }\end{array}$ \\
\hline Poland & $\begin{array}{l}\text { Regulation of the Prime Minister of } 12 \text { September } 2017 \text { on minimum wage and } \\
\text { minimum hourly wage in } 2018 \text { (Rozporzgdzenie Rady Ministrôw z dnia } 12 \text { wrzesnia } \\
2017 \text { r.w sprawie wysokosci minimalnego wynagrodzenia za pracg oraz wysokosci }\end{array}$ \\
\hline Portugal & Decree-Law No. 156/2017 (Decreto-Lei $n .^{\circ} 156 / 2017$ de 28 de Dezembro) \\
\hline Romania & $\begin{array}{l}\text { Governmental Decision No. } 846 / 2017 \text { on establishing the minimum basic gross wage } \\
\text { guaranteed (Hotârârea } n r .846 / 2017 \text { pentru stabilirea salariului de bazâ minim brut }\end{array}$ \\
\hline Slovakia & $\begin{array}{l}\text { Govenment Decree No. 278/2017 Coll., determining the level of minimum wage for } \\
2018 \text { (Nariadenie vlâdy c. } 278 / 2017 \text { Z. z., ktorym sa ustanovuje suma minimâlnej }\end{array}$ \\
\hline Slovenia & The statutory minimum wage for 2018 is published in Official Gazette No.5/2018 \\
\hline Spain & $\begin{array}{l}\text { The statutory minimum wage for } 2018 \text { was approved via Royal Decree Act } \\
1077 / 2017 \text { of } 29 \text { December after the agreement reached between government, trade } \\
\text { unions and employers' representatives }\end{array}$ \\
\hline UK & $\begin{array}{l}\text { At the time of writing ( } 24 \text { January 2018), regulations to implement the April } 2018 \\
\text { increases to the NLW and NMW have not yet been made }\end{array}$ \\
\hline
\end{tabular}

Source:

Unitary states with $M W$ are in favour of national uniformity, but no from the procedure of establishment, because access is equal and in countries with the centralized or collective-agreed method for setting minimum wages [10]. 
Convention No. 26/ILO permits MW differentiation for industries or sectors of industry and trade (including domestic production) in which "there is no established procedure for the effective regulation of wages by collective agreement or otherwise, and where wages are extremely low" (Art.1, ILO Convention No.26). The decision for which industries or sectors it will apply is made after consultation with workers 'and employers' organizations (Art.2/ILO Convention No.26). It was revised to a more detailed differentiation in Convention No.131 of the ILO, (Art.1, ILO Convention No.131, and see Table 1). Table 1 shows European countries that have signed the ILO MW Conventions European countries that have signed the ILO Conventions No. 26 (1928) and No. 131 (1970) for minimum wages

\subsection{European Minimum Wage}

EU market is the different height of European Minimum Wage (MW) and the way who the Member State pays MW or how are they use collective agreements (Figure 3). In scale, minimum wage by $84 \%$ from the population is unsatisfactory for life, while $70 \%$, enjoy social protection or not. Four billions of people (55\% of the world population) - do not use social benefits or benefits, and only $1 / 3$ from the people of the world use the comprehensive level of protection.

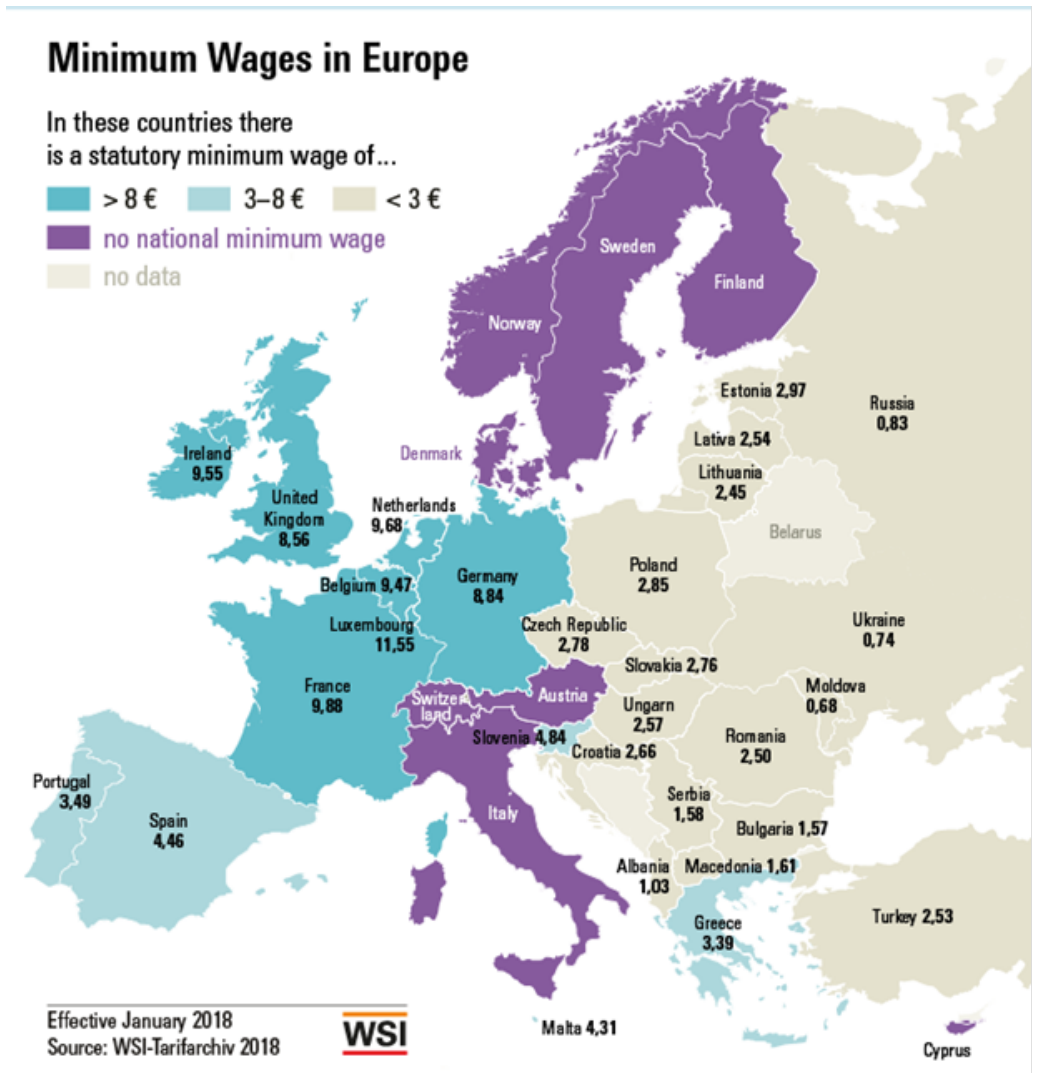

Figure 3. The Minimum Wage in EU

The freedom of association and collective bargaining, who are from central significance for common prosperity, are under deep attack. GDP is in the bottom line of financial gain from labour according to the upward productive line of labour in the previous four decades (the basis for the bottom line is the growth of economic process seen through their wages). The earth planetary wealth is for 3 times bigger from the previous four decades, but for unfortunately it is full of people who mostly hungry go to bed, in the context of guarantees from world leaders that we are free from "the bridge of poverty."Earth's planetary wealth is three times greater than in the previous four decades, but unfortunately it is full of people who go to bed mostly hungry, in the context of assurances from world leaders that we are free from the „bridge of poverty." The minimum wage in the 21 st century with EU enlargement means concern for wages and social status in new countries, as a result of the economic crisis. The EU Parliament (2007) announced that MW is under the level of existence in 
several countries and with that he called him the Council which adopted the MW directive to be $60 \%$ of salary. Collective bargaining in the EU is in decline (22 from the 27 EU member states (2000)) what is a consequence of tendency policies from EU members (approved from the European Commission), but of course because of the deformed image for high levels of collective bargaining that mostly were negative for the economy. The reality (is) emphasizes the opposite with facts that indicate that and strong systems for have collective bargaining share for higher wages and better working conditions, for a just society and a more effective economy. Romania (100\% to $23 \%)$, Greece $(100 \%$ to $25 \%$ ) Bulgaria (56\% to $23 \%$ ), had the largest percentage decline of workers according to the numbers from the University of Amsterdam (ictwss.org), and they established the worker covered number is in decline 9 out of 15 countries for which they are available data, including Greece $(-1.2$ million), Germany $(-884,000)$ and Hungary $(-439,000)$. The present is, Lithuania has $7 \%$ satisfied workers from collective agreements versus $98 \%$, Austrian pleasure. The data for decline by country is in Table 2 .

Table 2. Decreased Workers' Satisfaction with Collective Bargaining By Country [10]

\begin{tabular}{lccc}
\hline \multicolumn{1}{c}{ Member State } & $\begin{array}{c}\% \text { Coverage } \\
2000 / 02\end{array}$ & $\begin{array}{c}\% \text { Coverage } \\
2016 / 18\end{array}$ & $\begin{array}{c}\text { Difference in Number } \\
\text { of Workers Covered }\end{array}$ \\
\hline Lithuania & $15 \%$ & $7 \%$ & 59,000 \\
\hline Latvia & $18 \%$ & $14 \%$ & 1.263 million \\
\hline Poland & $25 \%$ & $17 \%$ & \\
\hline Greece & $100 \%$ & $25 \%$ & 259,000 \\
\hline Estonia & $23 \%$ & $19 \%$ & \\
\hline Hungary & $38 \%$ & $21 \%$ & \\
\hline Bulgaria & $56 \%$ & $23 \%$ & 10,000 \\
\hline Romania & $100 \%$ & $23 \%$ & 120,000 \\
\hline Slovakia & $51 \%$ & $25 \%$ & 884,000 \\
\hline Czech Republic & $35 \%$ & $30 \%$ & \\
\hline Ireland & $44 \%$ & $34 \%$ & \\
\hline Cyprus & $65 \%$ & $44 \%$ & \\
\hline Croatia & $64 \%$ & $45 \%$ & \\
\hline Malta & $57 \%$ & $50 \%$ & \\
\hline Germany & $68 \%$ & $54 \%$ & \\
\hline Luxembourg & $60 \%$ & $59 \%$ & \\
\hline Spain & $75 \%$ & $68 \%$ & \\
\hline Portugal & $78 \%$ & $74 \%$ & \\
\hline Netherlands & $82 \%$ & & \\
\hline & & $78 \%$ & \\
\hline
\end{tabular}

Some social partners through their European representative bodies were for individual mechanisms what are applying in/for each country, and that, because of the rights of national partners to participate in social dialogue. Employers are on the opinion that MW should be the sole responsibility of each country, according to the principle of subsidiarity.

The European Foundation for Conditions for life and work in European countries indicated that more than 1/4 from workers in Germany earn less from $60 \%$ from average salary, while in Finland the percentage is $6.8 \%$, in Austria $14.6 \%$ and in the UK $18.9 \%$. Also, the difference between the lowest wages and those who earn over $60 \%$ of the average salary is the highest in the EU. Although Cyprus there is no general legal minimum wage, has a statutory minimum wage for 6 specific occupations: sales staff, office staff, medical assistant and kindergarten staff, kindergarten and staff help in 
kindergarten and school. The fall of collective bargaining in Germany, for some researchers, unions and participants in the minimum wage campaign allows for the introduction of legal minimum [6]. National minimum (EURO, eiro. eurofound.eu.int/), is often combined through formulas, consultations with social partners, so and with negotiations. In Greece and Ireland, for example, it is part of negotiations for a major national agreement. In Portugal and Spain, governments estimate a minimum in price ratio, wages and productivity, and then, in consultation with the social partners, decide on the level of increase. In France, she "Formula" is related to prices and average wages, but there the government also has discretionary right to increase the minimum at any time. However, there is no recognized process of consultations in this country. We must conclude that the weak collective agreements carry the lowest wages in the EU (see. Table 3). Table 3 showing EU Member States in Order of Level of Median Gross Hourly Wage (low to high)

Table 3. EU Member States in Order of Level of Median Gross Hourly Wage [10]

\begin{tabular}{|c|c|c|c|c|}
\hline $\begin{array}{c}\text { Countries } \\
\text { (Lowest to } \\
\text { Highest Wages) }\end{array}$ & $\begin{array}{c}\text { Collective } \\
\text { Bargaining } \\
\text { Coverage }\end{array}$ & $\begin{array}{l}\text { Change in } \\
\text { Coverage } \\
\text { Since } 2000\end{array}$ & $\begin{array}{c}\text { No. of Workers } \\
\text { Covered }\end{array}$ & $\begin{array}{c}\text { No. of Workers } \\
\text { Not Covered }\end{array}$ \\
\hline Bulgaria & $23 \%$ & $-33 \%$ & 718,405 & $2.4 \mathrm{~m}$ \\
\hline Romania & $23 \%$ & $-77 \%$ & $1.9 \mathrm{~m}$ & $6.4 \mathrm{~m}$ \\
\hline Lithuania & $7 \%$ & $-8 \%$ & 92,834 & $1.2 \mathrm{~m}$ \\
\hline Latvia & $14 \%$ & $-4 \%$ & 121,968 & 749,200 \\
\hline Hungary & $21 \%$ & $-17 \%$ & 931,896 & $3.5 \mathrm{~m}$ \\
\hline Poland & $17 \%$ & $-8 \%$ & $2.7 \mathrm{~m}$ & $13.3 \mathrm{~m}$ \\
\hline Slovakia & $25 \%$ & $-26 \%$ & 637,150 & $1.9 \mathrm{~m}$ \\
\hline Czech Republic & $30 \%$ & $-5 \%$ & $1.5 \mathrm{~m}$ & $3.6 \mathrm{~m}$ \\
\hline Croatia & $45 \%$ & $-19 \%$ & 741,330 & 906,100 \\
\hline Estonia & $19 \%$ & $-4 \%$ & 121,752 & 519,000 \\
\hline Portugal & $74 \%$ & $-4 \%$ & 3443,738 & $1.2 \mathrm{~m}$ \\
\hline Slovenia & $71 \%$ & $-29 \%$ & 687,067 & 280,600 \\
\hline Greece & $25 \%$ & $-75 \%$ & 952,650 & $2.8 \mathrm{~m}$ \\
\hline Cyprus & $44 \%$ & $-19 \%$ & 179,960 & 229,000 \\
\hline Malta & $50 \%$ & $-7 \%$ & 128,100 & 128,100 \\
\hline Spain & $68 \%$ & $-7 \%$ & $13.4 \mathrm{~m}$ & $6.3 . \mathrm{m}$ \\
\hline Italy & $80 \%$ & No change & $18.1 \mathrm{~m}$ & $4.5 \mathrm{~m}$ \\
\hline Austria & $98 \%$ & No change & $4.2 \mathrm{~m}$ & 86,100 \\
\hline France & $94 \%$ & $-4 \%$ since 2014 & $25.2 \mathrm{~m}$ & $1.6 \mathrm{~m}$ \\
\hline Germany & $54 \%$ & $-14 \%$ & $22.4 \mathrm{~m}$ & $19.1 \mathrm{~m}$ \\
\hline Netherlands & $78 \%$ & $-4 \%$ & $6.8 \mathrm{~m}$ & $1.9 \mathrm{~m}$ \\
\hline Finland & $91 \%$ & $+6 \%$ & $2.2 \mathrm{~m}$ & 222,700 \\
\hline Belgium & $93 \%$ & $-3 \%$ & $4.4 \mathrm{~m}$ & 334,600 \\
\hline Luxembourg & $59 \%$ & $-1 \%$ & 169,389 & 117,700 \\
\hline Sweden & $90 \%$ & $-4 \%$ & $4.4 \mathrm{~m}$ & 492,400 \\
\hline Ireland & $34 \%$ & $-8 \%$ & 771,426 & $1.4 \mathrm{~m}$ \\
\hline Denmark & $82 \%$ & +5 & $2.2 \mathrm{~m}$ & 503,400 \\
\hline Total EU 27 & $61 \%$ & Not available & $119.6 \mathrm{~m}$ & $76.1 \mathrm{~m}$ \\
\hline
\end{tabular}

Countries with a minimum wage on collective bargaining: Austria, Belgium, Cyprus, Denmark, Finland, Greece, Iceland, Italy, Norway, Switzerland. Countries with minimum wage at the national level: Bulgaria, Croatia, Czech Republic, Estonia, France, Germany, Hungary, Ireland, Latvia, Lithuania, Luxembourg, Malta, Netherlands, Poland, Portugal, Romania, Slovakia, Slovenia, Spain, Great Britain. The only EU country without the minimum wage is in Sweden. Part-time job time or temporary work it is possible to be an important factor for low wages, especially when the workers resorted to atypical employment because of lack of full working time. In Sweden, local government is active in providing workers with abbreviated working time to be able to work with full working time. And the negotiations between the unions of public services and the Spanish government led to progress in the downsizing of Interim Contracts in public administration. Besides the change of the content of the low-paid workplaces, unions can work and to them help workers to get rid of low paid jobs, their vocational training should have a key role. The Danish government and social partners have announced the start of the project aimed at improvement of vocational training of workers who 
had only a short period of formal training (Unskilled workers, from the review for Denmark, EURO). They are in France led conversations in the domestic services sector to make the service professional, and at the same time to improve the quality of offered services. Collective agreement (eiro.eurofound.eu.int/2004) signed in March 2002. On basis all this, we can we conclude that exist 2 types of EU countries: With law supported with national minimum wage or with national intersectoral agreement, and with the collective agreement for minimum wage with supported negotiations of the social partners of the branch sector. (Figure 4) With Law, the minimum wage allows different EU member states to be supplemented with minimum benefits per collective labour agreement - and besides their difference in scope/national minimum level.

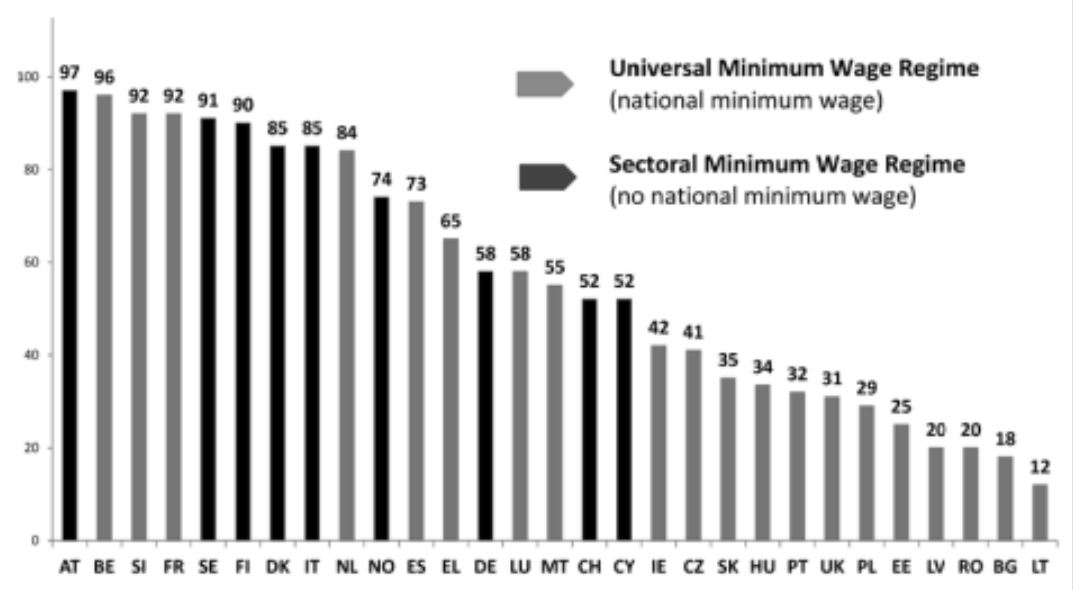

Figure 4. Minimum Wage, Regimes and Collective Agreement Coverage, 2009-2011 [10]

\subsection{Spread of Low Wages}

Eurostat (Focus on Statistics: Low-Wage Workers in the European Union, Eurostat, November 2000) for the situation with low wages across Europe were based on statistics from various countries related to 1995 . On basis to the extent of $60 \%$ from monthly salaries, Eurostat found that $15 \%$ of those who work 15 hours or more per week belong to the low paid category. Customized by the number of working hours, the percentage drops to $11 \%$ that varies from $6 \%$ in Portugal to $21 \%$ in the UK, and after working hours, the difference is from $4 \%$ in Belgium and Denmark to $16 \%$ in Greece. Low paid workers are women, young people, Migrants, workers on determined working time and in the service sector. There was not case employees in the public sector to have a lower salary than workers in the economy as a whole. Eurostat for the average earnings of men and women in different sectors gives indications for salaries in public services, and for the extent to which can be high or low paid in compared to the rest of the economy. For example, communal services (electricity, gas, water) usually are high wage industries, and according to Eurostat figures (Statistics provided at the request of EPSU, 2004), the average salary of men is greater in communal services than in the whole economy in all countries. In most countries, this difference is at least $10 \%$, but is much larger in Belgium $(61 \%)$, Greece (65\%) and Portugal (67\%). Belgium, France and the United Kingdom have little lower than their national averages, and state officials in Cyprus, Greece, Hungary and Switzerland receive average salary for $20 \%$ higher from national. In health and social services, the problem with low wages are more widespread, and women in this sector have to pay lower than the national average Eurostat.

In the Table 4, is the amount of salaries in the national currency until 2017, with a monthly minimum national salary: the lowest from only $29 €$ Estonia (1995) to $470 €$ (2017). The monthly earnings rely on compensation from the hour. Example: France started with $€ 5.46$ (1995) and $€ 7.61$ (2004) (employees with a 39-hour week and then a legal week of thirty-five hours). The minimum wage with a 35-hour week is based on a secured monthly salary, which allows salaries up to $€$ $1,286.09 /$ month. In 2003, the monthly minimum wage/35-hour week was - in relative correlation with the common wage -2.8 shared points, not up to the monthly reward that supported the 39-hour week. 
Naumovski Ljupcho.

Business Law Service in the Workplace as a Career Trend or to Wage Erosion - Minimum Wage.

International Journal of Law and Public Policy, vol. 3, no. 1, pp. 30-48, March 2021. DOI: 10.36079/lamintang.ijlapp-0301.183

Among the new Member States, the monthly minimum wage was $€ 120.26$ Latvia (1995), up to $€ 430$ lowest for 2020 .

Table 4. Minimum Wage Levels 2015 to 2017 [10]

\begin{tabular}{llccccc}
\hline \multirow{2}{*}{ Country } & \multirow{2}{*}{ Rate } & \multirow{2}{*}{ Currency } & \multicolumn{2}{c}{ Level of the Statutory mw } & Increase \\
\cline { 4 - 7 } & & $\mathbf{2 0 1 5}$ & $\mathbf{2 0 1 6}$ & $\mathbf{2 0 1 7}$ & $\mathbf{2 0 1 6 - 1 7}$ \\
\hline Bulgaria & Monthly & BGN & 380 & 420 & 460 & $9.52 \%$ \\
\hline Croatia & Monthly & HRK & 3029.55 & 3120 & 3276 & $5.00 \%$ \\
\hline Czech Republic & Monthly & CZK & 9200 & 9900 & 11000 & $11.11 \%$ \\
\hline Estonia & Monthly & EUR & 390 & 430 & 470 & $9.30 \%$ \\
\hline France & Monthly & EUR & 1457.52 & 1466.65 & 1480 & $0.91 \%$ \\
\hline Germany & Hourly & EUR & $/$ & 8.5 & 8.84 & $4 \%$ \\
\hline Hungary & Monthly & HUF & 105000 & 111000 & 127500 & $14.86 \%$ \\
\hline Ireland & Hourly & EUR & 8.65 & 9.15 & 9.25 & $1.09 \%$ \\
\hline Latvia & Monthly & EUR & 360 & 370 & 380 & $2.70 \%$ \\
\hline Lithuania & Monthly & EUR & 325 & 350 & 380 & $8.57 \%$ \\
\hline Luxembourg & Monthly & EUR & $/$ & 1922.96 & 1998.59 & $3.93 \%$ \\
\hline Malta & Weekly & EUR & 166.26 & 168.01 & 169.76 & $1.04 \%$ \\
\hline Netherland & Monthly & EUR & 1507.8 & 1524.6 & 1551.6 & 1.77 \\
\hline Poland & Monthly & PLN & 1750 & 1850 & 2000 & $8.11 \%$ \\
\hline Portugal & Monthly & EUR & 505 & 530 & 557 & $5.09 \%$ \\
\hline Romania & Monthly & RON & 1050 & 1250 & 1450 & $16.00 \%$ \\
\hline Slovakia & Monthly & EUR & 380 & 405 & 435 & $41 \%$ \\
\hline Slovenia & Monthly & EUR & 790.73 & 790.73 & 804.96 & $1.80 \%$ \\
\hline Spain & Monthly & EUR & 648.6 & 655.2 & 707.6 & $8.00 \%$ \\
\hline UK & Hourly & GBP & 6.7 & 7.2 & 7.5 & $4.17 \%$ \\
\hline
\end{tabular}

Current question:

How many minimum wage payments does an employee have per year?

The answer is in Table 5 .

Table 5. Minimum Wage Payments Does an Employee Have per Year [10]

\begin{tabular}{|c|c|}
\hline $\begin{array}{l}\text { Bulgaria, Croatia, Czech } \\
\text { Republic, Estonia, France, } \\
\text { Hungary, Latvia, Lithuania, } \\
\text { Netherlands (excluding }\end{array}$ & (Generally) 12 Minimum Wage Payments \\
\hline Belgium & $\begin{array}{l}\text { If workers receive a } 13 \text { th month payment, the total amount of what the } \\
\text { worker earns in a year is divided by } 12 \text { to see if the worker is at least } \\
\text { paid the minimum wage. }\end{array}$ \\
\hline Poland & $\begin{array}{l}\text { Only employees hired in the public sector (excluding the armed forces, } \\
\text { police and other uniformed services) are statutorily entitled to } 13 \text { wage } \\
\text { payments. Private sector employees get } 13 \text { payments only if this is } \\
\text { specified in the company's regulations. }\end{array}$ \\
\hline Greece & $\begin{array}{l}\text { Employees in the private sector in Greece are entitled to } 14 \text { monthly } \\
\text { wage payments. Employees in the public sector are entitled to } 12 \\
\text { monthly wage payments. }\end{array}$ \\
\hline Portugal and Spain & $\begin{array}{l}\text { Employees are entitled to } 14 \text { monthly wage payments per year. In } \\
\text { Spain, there are two 'extraordinary' payments allocated: one in June } \\
\text { and the other one in December }\end{array}$ \\
\hline Ireland, Malta & he minimum wage is set per hour or per week, not as a monthly rate. \\
\hline
\end{tabular}




\section{Today's Minimum Wage in Central Eastern European Countries (CEECs)}

At the beginning of 2019, the German Federal Minister for Labor Hubertus Heil (2019) noted that the creation of "European legal framework for minimum wages and minimum incomes" will be one from priorities for the presidency of the German Council of the EU in the second half of 2020. CEE has different legislation on labour investment. Table 5 shows the Lithuanian government is agreed to a $10 \%$ increase in the minimum wage, which increased it to $38 \%$ of the average salary, Estonia, by $8.5 \%$. (Employers and unions accounted for $41 \%$ of average earnings by 2008 [6].

The growth of nominal minimum wage January 2018 and January 2019, indicates growth from 5\% or more (CEE) and moves from Lithuania (38.4\%) Hungary (7.9\%), Poland (7.1) and Slovenia $(5.2 \%)$, of growth from $3 \%$ and $5 \%$, and quite a small increase of $3 \%$ Latvia $(-2.5 \%)$. The fast pace of growth of Lithuania is the result of more general calculations of gross wages what became necessary after tax reform shifted the tax burden from employers to employees. Such fast and strong growth in CEE countries means that the convergence of minimum wages in the EU had its rise in 2019 as shown in Figure 5.

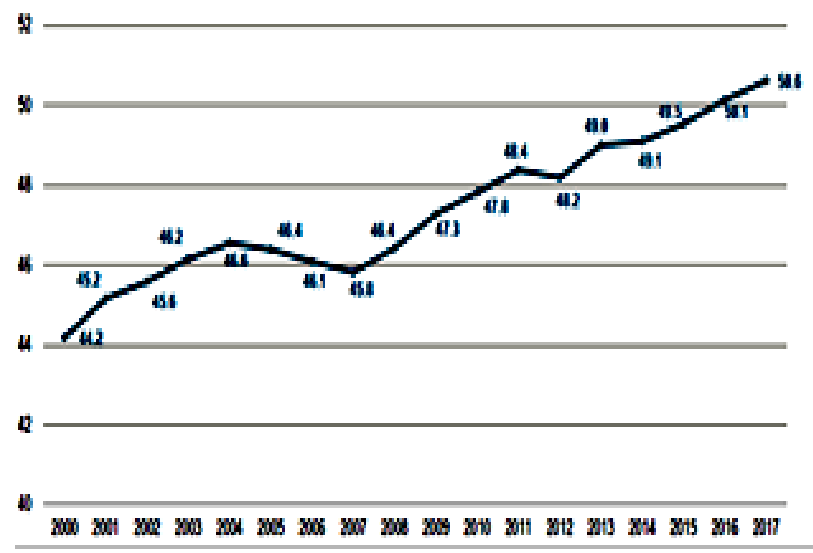

Figure 5. Change in the Relative Value of the Minimum Wage (Kaitz index) for the EU Average, 2000-17* Per Cent) [10]

Figure 5 sets it the movement for the EU as a whole, based on the median - that is the mid-point of national-level increases, ensuring that the number used, for the difference from the arithmetic mean, it is not distorted from extreme values: half from the countries involved have increased under this rate and a half above.

The numbers show that the trend towards a higher rate of increase what can be observed from 2017 so are to 2019 , with an average nominal rate of growth in comparison with the previous year of $4.8 \%$ and real growth of $2.7 \%$, also pretty high level.

Activated the growth of the minimum wage was at states with lower absolute minimum wages, but differences still exist.

The absolute level of (legal) minimum wages allows states with minimum wages between $€ 8$ and $€ 12$ (Western European countries), minimum wages between $€ 4$ and $€ 8$ (Slovenia/ $€$ 5.10) and Central and Eastern European countries with minimum wages below $€ 4$ (Lithuania/€ 3.39, Estonia (3, $€ 21)$, Czech Republic ( $€$ 3.11) and Poland (€ 3.05), Slovakia ( $€ 2.99)$, Croatia ( $€ 2.92)$, Hungary ( $€$ 2.69), Romania (€ 2.68) ) and Latvia (€ 2.54), below the 2 euro limit at the bottom is Bulgaria with $€$ 1.72 (according to the WSI minimum wage database), Serbia (€ 1.77), Macedonia (€ 1.63), Albania (€ 1.17) and below 1 euro Ukraine with $0.78 €$ for 2019 (according to the WSI minimum wage database) (Figure 6). 


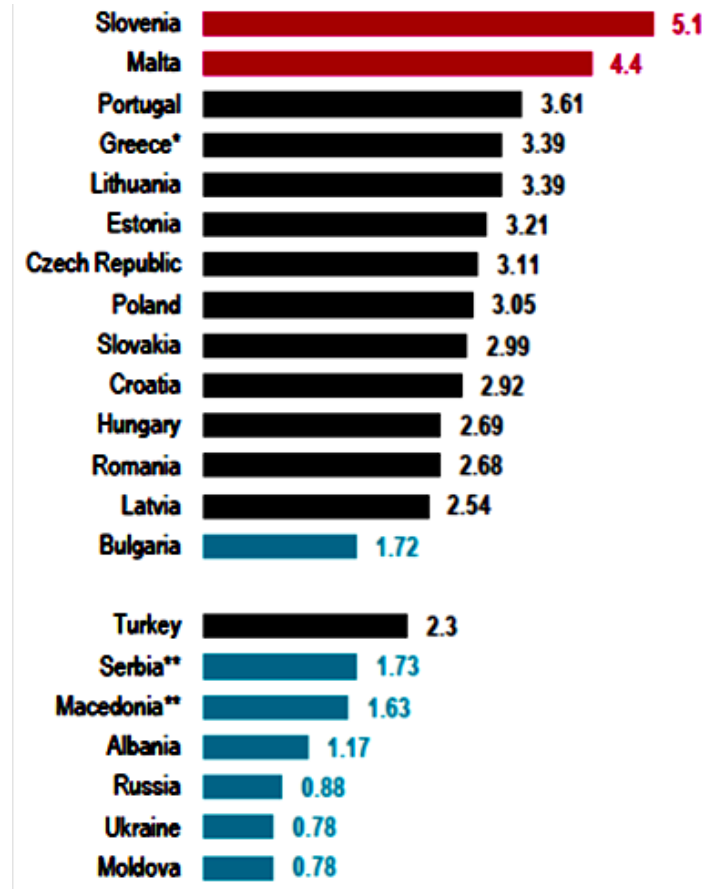

Figure 6. Statutory minimum wages, as at 1 January 2019 In Euro per hour [10]

The induced growth of the minimum wage is before thanks to the percentage of the national average or average salary with full working time, and the Keitz index is a relative measure (it is authoritative more for international comparisons than for the absolute level of the minimum wage). In during years, the minimum wage correlation - the average wage is actualized as a measure for the Kaitz index. The average salary by definition is salary what shares it the overall structure on the salary of two equal segments; i.e. she indicates the boundary between the highest-paid $50 \%$ and the lowestpaid $50 \%$ of employees.

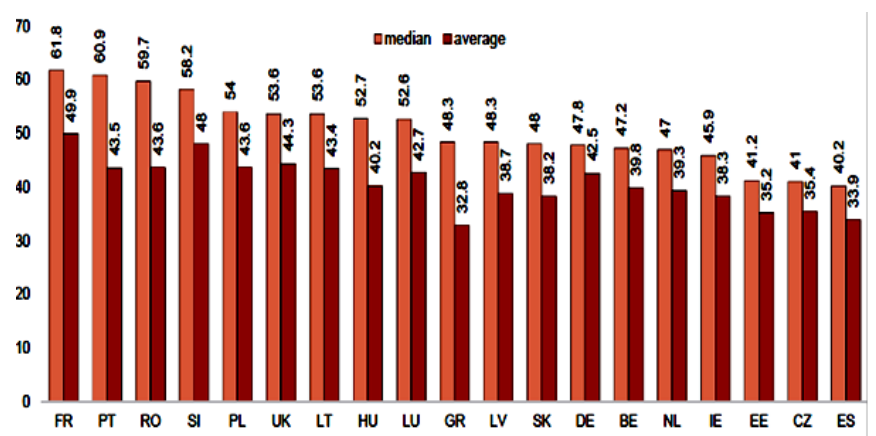

Figure 7. Minimum Wage as Percentage of National Full-Time Median and Average Wages (2017) [10]

Figure 7 shows minimum wages as a percentage of the national average and average salary in 2017, but not the latest increases in the minimum wage in 2018 and January 2019 (because OECD data always have a one-year lag).

EPSR is with the task to ensure "adequate minimum wages" what does it mean meeting the needs of the worker and the family, i.e. "poverty at work will be prevented" (European Commission 2017 b: 
27). EPSR not he explains the meaning the term "adequate" (employee and family needs) but alludes to the understanding of minimum wages that they are paying for life "More from simple existence what enables participation in society and a certain range for workers and their families to insure from unforeseen shocks "(Parker et al. 2016: 1). That's all exclusively for stopping at poverty in operation, and it will be a reality if the minimum wages are at least $60 \%$ of the national average salary with full working time as salary base for "Risk of poverty", for insurance of workers from state dependence (with tax credits or work benefits) what allows relaxation from poverty (European Parliament 2016: 35). Romania with $59.7 \%$, Slovakia $58.2 \%$, Poland 54\%, Ukraine with 53\% and lower with a bottom of $40.2 \%$ Estonia. The minimum wage had in the Czech Republic (41.0\%). Emphasizing that minimum wages do not provide a socially acceptable standard of living (European Parliament et al. 2017) inflamed political debates in many states, what resulted from the above-average increase.

In the last two decades, there is de facto progress in the increase in the minimum wage, with the Kaitz index for the (non-weighted) EU average of $44.2 \%$ in 2000 to $50.6 \%$ by 2017 in general. Figure 8 , proves that the Kaitz index is in upward line in the last two decades and grew up from $44.2 \%$ in 2000 to $50.6 \%$ in 2017 .

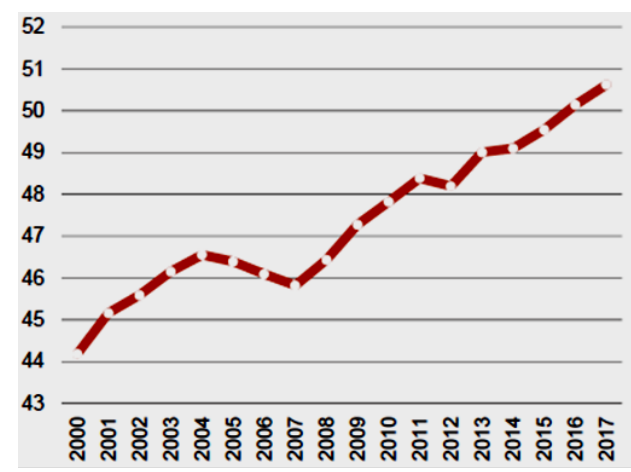

Figure 8. Development of the Kaitz Index: Minimum Wage as Percentage of Median Wage for Those Countries with a Statutory Minimum Wage (Annual Average, 2000-2017) [10]

But Figure 8 alarms that in 2017 is still $10 \%$ lower from the base of $60 \%$. If the base goal of $60 \%$, the minimum wage is the growth of total wages, then inevitably must be alluded to and directs to systems for negotiating with employers, for strengthening wages. In this moment of reality the base of $60 \%$, from a very low average salary does not meet the EPSR obligation that is the salary for meeting the needs of the worker and his/her family. The minimum wage is adjusted once a year in most countries, and that on January 1st. Principle 8 of EPSR alludes to encouraging actors for collective bargaining to negotiate and conclude agreements on issues of their importance while respecting their autonomy and the right to collective action [12]. For actuality of collective bargaining is the cover for collective bargaining, what does it mean employee participation covered by collective agreement. Figure 9 provides an overview of the scope of collective agreements in EU member states before and after the crisis.

Figure 9 directs its attention to collective bargaining in states by negotiating with multiple employers on the sectoral or cross-sectoral level. Important for collective bargaining is legal mechanisms for enlargement (or functional equivalents) that is to apply and for enterprises which do not sign the contract or are not members of the federation of employers which what signed an agreement and ample room for negotiation where what there is no legal mechanism for expansion and depends on the negotiating communication of both sides they negotiate. The lowest collective bargaining is with states with bargaining agreements with one employer. We emphasize, that these refer specifically on Central and Eastern Europe, the Baltic States, Hungary and Poland, where the scope decreased though was already on the pretty low level before the crisis. 


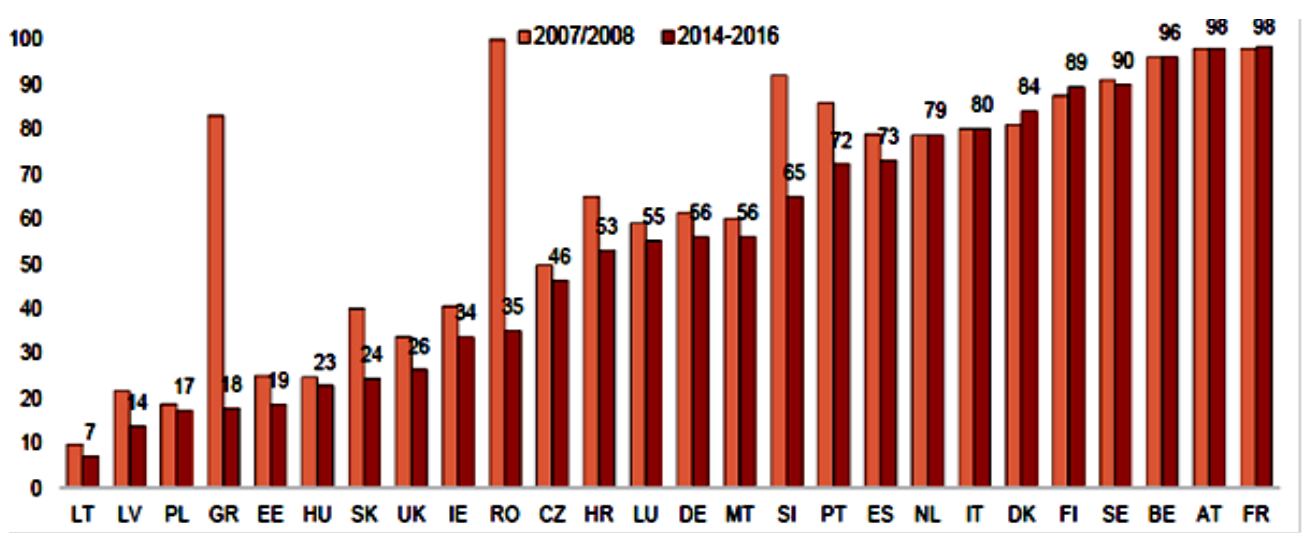

Figure 9. Collective Bargaining Coverage before and after the Crisis (2007/2008 and 2014/16) (Percentage of Workforce) [10]

The biggest drop of collective agreements in the crisis was on the blow of measures what wore decentralization of collective bargaining and/or cancelled or restricted legal mechanisms for enlargement, such as Lithuania with 93 percentage points, Latvia with 86 percentage points, Poland 83 , Estonia with 81 , Hungary ( -77 points), Slovakia -76 points, Ukraine -74 points, Romania with a decrease of 65 percentage points, Czech Republic 54 percentage points, Croatia from 47 percentage points, Slovenia (-27 pp), Slovakia (-16 pp). Despite the fall of collective agreements, however, there is a need for political support when unions are unsuitable for conducting negotiations. Recommendations for solving of wages in the Czech Republic and Estonia by increasing participation in the women's labour market that is the convergence of wages between men and women, these recommendations are an attempt for security adequate wages for women. Croatia wants to reform the determination of public salaries for bigger control over salaries of the public sector. Bulgaria and Romania - both states with the lowest absolute minimum wage, but with the highest growth of the minimum wage are asked for greater transparency in determining the minimum. CSRs in 2018 are currently in that do not include than for what they do, without participation in the field of wages and collective agreements, for example, recommendations for restart systems for collective bargaining with more employers, which are destroyed in crisis years, recommendations for providing fair wages for a decent living standard and appropriate minimum wages for satisfaction to the needs of workers and their families. Trade union membership is declining, from 52 million members in 1990 to 37 million members in $2015,(29.2 \%)$ with a relatively high level among social groups exposed to economic vulnerability as young and migrant workers [13]. On the lowest branch are most states from Central and Eastern Europe with exception to Croatia, Slovenia and Romania, but the fall started and in these states. A large number of workers receive cash over the minimum wage, and others through everyday activities elsewhere, which results from negatives as for funding from the government, but and for workers' social protection. Another negativity - arrears of wages and non-compliance with minimum wage, (Ukraine March 2018), for example, according to estimates of State Statistics Office, arrears reached 2.5 billion UAH/78 million euros. The low legally minimum wages no motivate for collectively organizing and negotiating for dignified pay over minimum wages and therefore on a blow to the trade unions. The Global Labor Rights Index [9] shows that trade union rights have been systematically or regularly violated in Romania, Bulgaria, Albania, Northern Macedonia and Serbia (ranked 3 and 4) and that there are no guarantees for trade union rights in Ukraine ranked 5.

In general, has taken, long-term, but an uneven decline in the volume of the strike reflects the reduction of the importance of industrial unionism, as well as a change of strike activity to private service sectors, especially in within transport and logistics, where strikes have tended to be short, and sometimes smaller, due to their transverse capacity [14]. 


\section{Real correlation EU - Central and Eastern Europe}

Central and Eastern Europe from 1990 until 2018 are in growth versus Western and Southern Europe. The Czech Republic with a growth of $2.4 \%$ of GDP per resident is an exception, closer to Southern Europe. Ireland and Malta (tax paradise) are with great growth, while Germany, France, Great Britain and Italy, with the growth of GDP per capita resident below the European average. Economic growth notes slowed down the line in 2018, without Ireland, Poland, Hungary, Slovakia, Greece, Sweden and Luxembourg. But the attitude of the European Commission (European Economic Forecast, Brussels, 2019 ) is that it will be up 1.1\% in 2019 for Europe in general, with the exception of Malta, Bulgaria, Croatia, Greece, Denmark, Great Britain and Luxembourg which are not noticeable (growth in stagnation or with very low accelerations). Him self slowing down in Central and Eastern Europe, in fact, meant returning of economies of Western Europe (including Germany) at growth rates less than $1 \%$. Southern Europe - specifically Italy - will be less developed [15].

The industry resulted in the European economy in 2018 and the first part of 2019, a decline in industrial activity, but not in all states. Production growth continued in the states from Central and Eastern Europe to the Baltic States and, somewhat surprisingly, to the UK. CEE was with the strongest industrial growth between March 2018 and March 2019, from 8.7\%, is registered in Poland, in compared with only $2.3 \%$ in the Czech Republic.

In Romania, are increased by $3.8 \%$, far above the European average, but under the level observed in Poland, Slovakia, Hungary or Bulgaria. The reduced German industrial production from $2.3 \%$ leave consequences on Eastern Europe, Romania, was tied in German chains of production. Eastern states from January 2008 to January 2019 showed the degree of a new wave of industrialization, while most western and southern states passed through sharp industrial fall - again, Germany is the most important exception. Growth in 2018, is greater than in 2017 (1.2\% compared to $0.7 \%$ in the case of average real salary per employee), the evolution of salaries remains under expectations, especially if the account for the increased employment and labour market participation. (Eurostat, Euro found European Restructuring Monitor).

In the European Union, the increase in the fee is with less on the distribution of value-added, employee salary share in GDP are increased by $62.8 \%$ in 2017 , to $63.2 \%$ in 2018 , and the forecast for 2019 was $63.4 \%$. The most important increase is in Romania (from 53.6\% to 55.6\% - level similar to 2008), as a result of government official policy for an increase in wages in GDP. Others significant increases are occurred in the Czech Republic $(+2.1$ percentage points), Hungary $(+1.5$ percentage points) and Denmark (+ 1.4 percentage points).

In Slovenia, Bulgaria, Austria, Finland, Luxembourg, Cyprus, Malta and Ireland, the fee of employees did not keep up with GDP growth and respectively decreased and the participation of wages in GDP. In 12 states, including Romania, salary share of employees in GDP was lower in 2018 than in 2008.

2019, European Commission estimates smaller variations of this indicator, with a considerable increase for Romania ( +2.8 percentage points) and Poland $(+1$ percentage point $)$.

\section{Conclusion}

Based on a study of the regulatory and legal framework, whose volume does not provide in detail study of all issues in connection with the procedure for setting the minimum wage, can to pull out conclusions: The currently established minimum wage does not meet them the basic principles of legal regulation of wages and state guarantees for salaries; Problems with its application are not resolved on the legislative level.

Like that, according to the authors, solving the identified problems are (possible):

- First: Bringing consumer basket in modern socio-economic realities, determining the minimum wage of level not lower from the level of existence; Necessary determination clear description of the minimum wage in the legislation, according to which the fee, stimulation and social payments not to be involved in the minimum wage. Use of minimum wage: for paid list; for payment of a fee to the detriment caused from injury, occupational disease or other damage to healthrelated to the execution of work tasks; for all other calculations, using another value and name and adjustment of all regulations in consent with this. 
- Second: Refuse to determine the minimum wage in the form in which are apply now; Using the positive experience and, determine legislative another state guarantee for minimum wage.

The first way to solving of problems required minimum costs, but also them solves problems only soon, the second way is longer and more laborious, but, according to the authors, is more branch.

\section{References}

[1] B. Milanovic, Global Inequality: A New Approach for the Age of Globalization. Harvard University Press, 2016.

[2] D. Grossman, "Map of Central and East Europe," September 2005. [Online]. Available: https://www.researchgate.net/figure/Map-of-Central-and-East-Europe-region-of-investigationis-marked-with-a-bold-line_fig1_220835076. [Accessed: Sept. 2, 2020].

[3] L. Andor, "Fair Mobility in Europe," Social Europe Occasional paper 2015.

[4] W. Keynas, and L. Wojciechowski, "Determinants of inward FDI into Visegrad countries: Empirical evidence based on panel data for the years 2000-2012," Economics and Business Review, vol. 2, no. 1, pp. 34-52, 2016.

[5] Lj. Naumovski, "Unemployment an Unauthorized Unique Road about Apathy and Poverty the Macedonian Man without Knowledge and Skills," International Research Journal of Management, IT \& Social Sciences (IRJMIS), vol. 4, no. 4, pp. 39-50, July 2017. 10.21744/irjmis.v4i4.518

[6] European Commission. European Semester - Country specific recommendations, Communication from The Commission to the European Parliament, the European Council, the Council, the European Central Bank, the European Economic and Social Committee, the Committee of The Regions and the European Investment Bank, 23 May 2018.

[7] IMF, Taking Stocks of Monetary and Exchange Rate Regimes in Emerging Europe. IMF European Department. 2016.

[8] EBRD, Transition Report 2018-2019. EBRD, 2019.

[9] EBRD, Eight Things You Should Know About Middle. Income Transition, 2019.

[10] OECD, Under Pressure: The Squeezed Middle Class. OECD, 2019.

[11] K. Wach, and L. Wojciechowski, "Determinants of inward FDI into Visegrad countries: Empirical evidence based on panel data for the years 2000-2012," Economics and Business Review, vol. 2, no. 1, pp. 34-52, 2016.

[12] R. Baldwin, "Global Value Chains: Why they emerged, why they matter, and where they are going," CEPR Discussion Paper 9103, 2012.

[13] L. Alfaro, and M. X. Chen, "Surviving the Global Financial Crisis: Foreign ownership and establishment performance," American Economic Journal: Economic Policy, vol. 4, no. 3, pp. 30-55, 2012.

[14] A. Zlate, "Offshore Production and Business Cycle Dynamics with Heterogeneous Firms," Journal of International Economics, vol. 100, pp. 34-49, 2016.

[15] D. Goldschmidt, and J. F. Schmieder, "The Rise of Domestic Outsourcing and the Evolution of the German Wage Structure, The Quarterly Journal of Economics, vol. 132, no. 3, pp. 11651217, August 2017. 